\title{
The Role of Competence on The Leadership Effect on Employee Performance of Micro, Small and Medium Enterprises
}

Submitted Date :

16 July 2021

Accepted Date :

11 August 2021

\author{
Aniek Rumijati* \\ University of Muhammadiyah Malang \\ rumijati@umm.ac.id
}

Suggested Citation:

Promis, P. (2008). Are Employer Asking for Right Competencies. Library Administration and Management, 22(1)

Abstract:

This study aims to describe leadership, competence, and employee performance; analyze the influence of leadership on employee performance in Micro Small Medium Enterprises (MSMEs) both directly and through employee competence as a mediating variable. Data collection used a survey method, with a questionnaire as a tool. The population is employees in MSMEs. The sampling technique used purposive sampling with a total of 83 respondents. The analytical method used is a Scale Range and path analysis with the Smart PLS3 program. The results of the study showed that leadership is very good, the competence and performance of employees are very high; leadership has a significant effect on employee performance directly, as well as through competence mediation variables.

Keywords: Competence; Employee Performance; Leadership

JEL Classification: 01

*Corresponding Author 


\section{Research Background}

The role of micro, small and medium enterprises (MSMEs) at this time are very important Because this company can absorb a huge number of employees and has a strong defensive capability. Due to the unpredictability of the economy, many businesses act wisely by downsizing they have. With the increase in population, causing the problem of unemployment in Indonesia is quite high. The alternative solution used is to open jobs through small, micro and medium enterprises. MSMEs is the foundation of Indonesia's economy, with total population over 62 million in 2017, and to grow more than 64 million in 2018, as stated in BPS Report. For this reason, the Indonesian government, through the Ministry of Cooperatives and Small and Medium Enterprises, encourages citizens to create new enterprises. In Malang, MSMEs have increased rapidly from year to year, namely in 2014 as many as 77.000 increased to 113.000 MSMEs in 2018. The MSMEs business sector in Malang consisted of Furniture, culinary, convection, handicrafts, automotive, and forest products. The increase in MSMEs must be accompanied by assistance from various parties, namely the role of government and universities. The main problems of MSMEs basically consist of capital issues, product standardization, marketing, and human resources.

Human resources are the most important assets for the company. Although MSMEs require relatively few employees compared to large companies, a high quality human resources are needed in business success. In order for business sustainability in the long term to continue, role of leader is very important in managing human resources so that each employee makes a maximum contribution to the company. The leaders can encourage employees to work optimally so as to improve employee performance. According to Irjanto \& Setiawan (2016) leadership style is influential in improving employee performance in the MSME industry, while in other studies, Sukwadi \& Yonathan (2014) found leadership styles to have a negative influence on employee performance. This reinforces the findings of Bass \& B.J (1994) that transactional leadership especially reward-based leadership and exception management does not function well and tends to negatively affect employee performance. For this reason, the right leadership style is very important in influencing employee performance, especially in MSMEs because the number of employees with relatively few relationships between employees and superiors or owners is very close.

In addition to leadership, competence is one of the factors that influence employee behaviour and performance (McShane \& Von Glinow, 2000). Spencer \& Spencer (1993) state that competence is a basic characteristic that at least includes motives, attitudes, self-concepts, knowledge, and skills. Competence can be a differentiator between individuals who have superior performance or not. Competencies can be divided into soft competencies and hard competencies. Employee performance can be improved through soft competencies (flexibility, communication, and creativity) McBer (1996) and hard competencies (knowledge and skills). Although soft and hard competencies can affect employee performance, soft competencies or soft skills significantly affect employee performance compared to hard competencies and are proven to be needed for all types and levels of work in the professional world of work (Promis, 2008). Martadiredja (2010) found that competence has a significant effect on performance. The forming factors of employee soft competence are individual commitment in achieving life goals, enforcement of rules, social roles played by someone, a mentor and the quality of mentors both in the workforce and in the family. In the world of work the role of leaders as mentors in guiding employees, in general, makes employees will master soft competencies more optimally in accordance with their basic abilities (Aris et al., 2011). For this reason, competence is an important variable used in mediating the influence of leadership on employee performance. The purpose of this study is to: (1) describe leadership, competence and employee performance; (2) analyze the influence of leadership on employee performance directly; (3) analyze the role of employee competence as a mediation on the influence of leadership on employee performance

Hasibuan (2006) explained that performance is the result of work achieved by someone in carrying out the tasks assigned to him based on skills, experience, sincerity and time. Whereas Rivai \& Mulyadi (2009) argued that employee performance is a set of results achieved and refers to the actions of achievement and the implementation of the work requested. Prawirosentono (1999) stated that there are three groups of variables that influence work behaviour and individual performance, namely: individual variables, organizational variables, and psychological variables. Individual variables consist of abilities and skills, personal and demographic backgrounds. Psychological variables consist of variables of perception, attitude, personality, learning, and motivation, while the organizational variable group consists of resource variables, leadership, rewards, structure, and design work. 
Leadership is a process to influence others to understand and agree with what needs to be done and how the task is carried out effectively, as well as a process to facilitate individual and collective efforts to achieve common goals(Yukl, 2010). Whereas Northouse (2003) argues that leadership is a process of influencing individuals and groups to achieve general goals. The theory of transformational and transactional leadership is also called the agent change theory emphasizing the right alternative leadership to anticipate and make changes in both the internal and external environment. According to Yukl (2010) with transformational leadership, followers feel trust, admiration, loyalty, and respect for leaders and they are motivated to do more than initially expected of them. Whereas conversely transactional leaders according to Robbins \&Judge (2008) are leaders who motivate employees in the direction of goals that are enforced by clarifying and demanding tasks.

Employee competence is a characteristic that underlies a person in doing work and is related to the effectiveness of one's performance in their work. The type of employee competence consists of (1) intellectual competence, emotional competence and social competence (Spencer \& Spencer, 1993). Whereas Arie (2012)states employee competence consists of knowledge, abilities/skills (skills), attitudes, situations. Factors that shape competence according to Abdullah (2013) are Knowledge; Skills; Self-concept; (4) Characteristics; (5) Motives. The relationship between performance, competence, and leadership was stated by Abdullah (2013)that employee performance should be done in accordance with the instructions given by the leadership, determined the competence and ability of employees in developing their potential.

\section{Research Method}

This research is an explanatory study which aims to explain causality between variables through hypothesis testing. The population is employees in Micro, Small and Medium Enterprises in Malang. This research used a non-probability sampling. The technique of collecting data using a questionnaire. The measurement scale uses a Likert scale with 5 alternative answers, value 1 for strongly disagree to 5 to strongly agree. Hair et al. (2015) determined that the maximum number of samples is 300 when the construct is 7 , communality is at least 0.45 , and the indicator or invalid item in each construct is fewer than three. The goal of this study, which is expected to have a maximum of 300 samples, is to give reliable data so that the study's outcomes are more realistic. The sample size in this study was determined by looking at the huge number of variables investigated and determining the smallest number of samples (Cooper \& Schindler, 2014). With a variable of 5 , the minimum number of samples is determined, and the total number of samples is 100 . The sample approach used in this study is non-probability sampling, which is used when the population size is unknown.

The leadership variables used are transformational and transactional leadership adopting the multifactor leadership questioner Bass \& Avolio(1994) which consists of 7 indicators: ideal influence, inspirational motivation, intellectual stimulation, individual consideration and contingent reward, active and passive management with the exception. Employee performance is measured using indicators of quantity, quality, and timeliness Hasibuan (2006) while competence is measured by indicators of intellectual competence, social competence, emotional competence refers to the opinion of Spencer \& Spencer (1993).

The data analysis technique used Scale Range to describe leadership, competence and employee performance and inferential statistics with path analysis using Smart PLS 3 to test the effect of leadership on employee performance both directly and through mediating competence variables. The Sobel test is used to test the significance of competence mediation the effect of leadership on employee performance and examination tests used to test the nature of mediation.

\section{Result}

\section{Characteristics of Respondents}

Respondents in this study were employees of MSMEs in the city of Malang, with the number of respondents as many as 83 people in furniture and shoes/sandals firms. Characteristics of respondents were identified based on age, sex, education, family status and length of employment. Based on the age of the majority of respondents ranged 21 to 30 years old (as many as 37.3\%); male sex (83.15); the majority of high school education level. 
Based on the results of data analysis using Scale Range Analysis the average score shows 353.64 (between scores 347-412) which means that leadership used by leaders in the category is very good or very effective. The results of the analysis are shown in the following table 1:

Table 1. Description of the Variables of Leadership

\begin{tabular}{|c|c|c|c|c|c|c|c|}
\hline \multirow{2}{*}{ Item } & \multicolumn{5}{|c|}{ Respondent's answer } & \multirow{2}{*}{$\begin{array}{l}\text { Total } \\
\text { Score }\end{array}$} & \multirow{2}{*}{ Information } \\
\hline & 5 & 4 & 3 & 2 & 1 & & \\
\hline X1.1 & 43 & 30 & 10 & - & 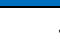 & 365 & Very good \\
\hline X1.2 & 39 & 33 & 11 & - & & 360 & Very good \\
\hline X1.3 & 37 & 33 & 13 & - & & 356 & Very good \\
\hline X1.4 & 34 & 27 & 21 & 1 & & 343 & Good \\
\hline X1.5 & 34 & 35 & 14 & - & & 352 & Very good \\
\hline X1.6 & 41 & 28 & 14 & - & & 359 & Very good \\
\hline X1.7 & 37 & 33 & 13 & - & & 356 & Very good \\
\hline X1.8 & 14 & 44 & 25 & - & & 321 & Good \\
\hline X1.9 & 43 & 27 & 13 & - & & 362 & Very good \\
\hline X1.10 & 47 & 23 & 13 & - & & 366 & Very good \\
\hline X1.11 & 38 & 30 & 12 & 3 & & 352 & Very good \\
\hline X1.12 & 47 & 23 & 13 & - & & 366 & Very good \\
\hline X1.13 & 34 & 23 & 23 & 3 & & 337 & Good \\
\hline X1.14 & 36 & 35 & 12 & - & & 356 & Very good \\
\hline & Avera & Score & & & & 353.64 & Very Good \\
\hline
\end{tabular}

Source: Data Processed (2020)

Employee competencies in this study used 3 indicators, namely intellectual, emotional and social competencies which were described in 6 items of questions. The results of the analysis show employee competence in the high category with a score of 365.66 (between scores 347-412). The results of the analysis are shown in the following table:

Table 2. Description of Competence Variables

\begin{tabular}{lrrrrrrrr} 
& \multirow{9}{*}{ Item } & \multicolumn{9}{c}{ Respondent's answer } & \multicolumn{2}{c}{ Total } & \multirow{2}{*}{ Information } \\
\cline { 2 - 6 } & 5 & 4 & 3 & 2 & 1 & Score & Very High \\
X2.1 & 40 & 34 & 9 & - & - & 363 & Very High \\
X2.2 & 46 & 28 & 9 & - & - & 369 & Very High \\
X2.3 & 43 & 33 & 7 & - & - & 368 & Very High \\
X2.4 & 39 & 35 & 9 & - & - & 362 & Very High \\
X2.5 & 40 & 32 & 11 & - & - & 361 & Very High \\
X2.6 & 46 & 30 & 7 & - & - & 371 & Very High \\
& Average Score & & & & 365.66 &
\end{tabular}

Source: Data Processed (2020)

Employee performance in this study uses 3 indicators consisting of quantity, quality, and timeliness. The results of the analysis show that the average employee performance score is 356.67 (between scores 347-412) in the very high category. The results of the analysis are shown in table 4 below:

Table 3. Description of Employee Performance

\begin{tabular}{lcccccccc} 
& \multicolumn{9}{c}{ Respondent's answer } & Total & Information \\
\cline { 2 - 7 } & 5 & 4 & 3 & 2 & 1 & Score & Very High \\
X2.1 & 40 & 34 & 9 & - & - & 363 & Very High \\
X2.2 & 46 & 28 & 9 & - & - & 369 & Very High \\
X2.3 & 43 & 33 & 7 & - & - & 368 & Very High \\
\hline
\end{tabular}

Source: Data Processed (2020)

The analytical tool used is path analysis using smart PLS 3.0 programs. Outer measurement model consists of (1) Convergent Validity; (2) Average Variance Extracted (AVE) and (3) Composite Reliability. Based on the results of the analysis show that all constructs produce a loading value of 60.6 , which means that all 
constructs are valid, while to test reliability is evaluated using AVE and Composite Reliability. If the AVE value is $>0.50$, then the construct meets reliable requirements, while the composite reliability value is considered very good if the value is $>0.70$ (Ghozali \& Latan, 2015).

Table 4. Convergent Validity Test Results

\begin{tabular}{|c|c|c|c|}
\hline Variable & Item & Outer loading & Description \\
\hline \multirow[t]{14}{*}{ Leadership } & $\mathrm{X} 1.1$ & 0.820 & Valid Convergent \\
\hline & $\mathrm{X} 1.2$ & 0.863 & Valid Convergent \\
\hline & $\mathrm{X} 1.3$ & 0.859 & Valid Convergent \\
\hline & $X 1.4$ & 0.834 & Valid Convergent \\
\hline & X1.5 & 0.890 & Valid Convergent \\
\hline & X1.6 & 0.893 & Valid Convergent \\
\hline & $\mathrm{X} 1.7$ & 0.810 & Valid Convergent \\
\hline & $X 1.8$ & 0.636 & Valid Convergent \\
\hline & X1.9 & 0.839 & Valid Convergent \\
\hline & $X 1.10$ & 0.886 & Valid Convergent \\
\hline & $\mathrm{X} 1.11$ & 0.894 & Valid Convergent \\
\hline & $\mathrm{X} 1.12$ & 0.884 & Valid Convergent \\
\hline & $X 1.13$ & 0.835 & Valid Convergent \\
\hline & $\mathrm{X} 1.14$ & 0.876 & Valid Convergent \\
\hline \multirow[t]{6}{*}{ Competence } & $X 2.1$ & 0.916 & Valid Convergent \\
\hline & $X 2.2$ & 0.874 & Valid Convergent \\
\hline & $X 2.3$ & 0.866 & Valid Convergent \\
\hline & $X 2.4$ & 0.824 & Valid Convergent \\
\hline & $\times 2.5$ & 0.850 & Valid Convergent \\
\hline & $X 2.6$ & 0.700 & Valid Convergent \\
\hline \multirow[t]{3}{*}{ Employee Performance } & Y1 & 0.948 & Valid Convergent \\
\hline & Y2 & 0.975 & Valid Convergent \\
\hline & Y3 & 0.974 & Valid Convergent \\
\hline
\end{tabular}

Source: Data Processed (2020)

The results of the outer model analysis show that the value of the loading factor of all items used is $>0.5$ so it is concluded that all items used in the questionnaire are valid. Reliability testing produces AVE values $>$ 0.50 and composite reliability $>0.70$ so the variables are declared reliable. The results of the analysis are shown in the following table:

Table 5. Analysis Measurement Model

\begin{tabular}{cccc}
\hline Variable & AVE & Composite Realibility & Information \\
Leadership & 0.694 & 0.969 & Reliable \\
Employee Performance & 0.900 & 0.964 & Reliable \\
Competence & 0.650 & 0.917 & Reliable \\
\hline
\end{tabular}

Source: Data Processed (2020)

Testing of the goodness of fit model can be seen from the predictive-relevance value $\left(Q^{2}\right)$. The value of $R^{2}$ variable employee performance is 0.786 ; while the $R^{2}$ value of the competence variable is 0.643 .

Thus the predictive-relevance value $\left(Q^{2}\right)$ is obtained as follows:

$$
\begin{aligned}
& Q^{2}=1-\left(1-R 1^{2}\right)\left(1-R_{2}^{2}\right) \\
& Q^{2}=1-(1-0.786)(1-0.643) \\
& Q^{2}=0.9236
\end{aligned}
$$

The results of the calculation of predictive-relevance $\left(Q^{2}\right)$ value are 0.9236 or equal to $92.36 \%$ so that the model is said to be feasible and has relevant predictive value. This value explains that the diversity of data built with the PLS model from the variables studied is $92.36 \%$ and the remaining $7.64 \%$ is explained by variables not 
examined and errors. These results indicate that the PLS model formed is very good because it can explain $92.36 \%$ of the overall information.

\section{Hypothesis Testing and Direct Influence Coefficient}

Testing hypotheses and path coefficients directly influence the leadership variables, competencies on employee performance seen from the path coefficient values, $t$ statistics, and $p$-value. The results of testing the hypothesis of direct influence can be seen in Table 6 below.

Table 6. Results of Direct Effect Hypothesis Testing

\begin{tabular}{cccccc}
$\begin{array}{c}\text { Independent } \\
\text { Variable }\end{array}$ & Dependent Variable & Coefficient Path & $\mathrm{t}$ statistic & p-value & Description \\
Leadership & Employee performance & 0.437 & 3.643 & 0.000 & Significance \\
Leadership & Competence & 0.802 & 15.797 & 0.000 & Significance \\
Competence & Employee performance & 0.497 & 4.345 & 0.000 & Significance \\
\hline
\end{tabular}

Source: Processed Primary Data, 2020

\section{Effect of Leadership on Employee Performance}

Testing the direct effect of Leadership on Employee Performance obtained the path coefficient of 0.437 with tstatistics of 3,643 and $p$-value of 0,000 . Because the t-statistic value is $3,643>1.96$ and $p$-value is $<0.05$, then leadership has a significant effect on employee performance. These results prove that leadership has a direct and significant effect on employee performance. If leadership getting better or more effective, leadership will improve employee performance, and conversely the worse or ineffective leadership will reduce employee performance. This findings same as Irjanto \& Setiawan (2016), stated that leadership style is influential in improving employee performance in the MSMEs industry.

\section{Effect of Leadership on Competence}

Testing the direct effect of Leadership on Employee Performance obtained the results of the path coefficient of 0.802 with t-statistics of 15.797 and $p$-value of 0.000 . Because the t-statistic value is $15,797>1.96$ and $p$-value is $<0.05$, then leadership has a significant effect on employee competence. If leadership getting better or more effective, leadership will improve employee competence, and conversely, worse or ineffective leadership will reduce employee competence. McShane \& Von Glinow (2000) which stated that leadership become one of the factors that increase the employee's competence.

\section{Effect of Competence on Employee Performance}

Testing the direct effect of Competence on Employee Performance obtained the path coefficient of 0.497 with tstatistics of 4,435 and $p$-value of 0,000 . Because the t-statistic value is $4.435>1.96$ and $p$-value $<0.05$, competence has a significant effect on employee performance. The higher employee competence will improve employee performance, and conversely the lower the competence it will reduce employee performance. Martadiredja (2010) found results that competence had a significant effect on performance.

\section{Effect of Leadership Testing on Employee Performance with Competence as a mediating variable}

Tests are carried out by procedures developed by Sobel test. The Sobel test uses free Sobel software test calculator or the significance of mediation version 4.0. The results of the Sobel test analysis are shown in Table 7 below:

Table 7. Sobel Test Result 


\begin{tabular}{llllllll}
\hline $\begin{array}{l}\text { Leadership-Competencies- } \\
\text { Performance }\end{array}$ & 0.802 & 0.497 & 0.051 & 0.114 & 4.2012 & 0.000 & Significant \\
\end{tabular}

Source: Processed Primary Data, 2020

The results of the analysis of the influence of leadership on employee performance by mediating competencies indicate that competence mediates the influence of leadership on employee performance. Besides the nature of the relationship using the examination method shows that the nature of the mediation of competence on the influence of leadership on employee performance is partial mediation.

\section{Discussion}

The results of the analysis using a range of scales indicate that leadership used in MSMEs is very good, meaning that the indicators of transformational and transactional leadership consist of 7 indicators: ideal influence, inspirational motivation, intellectual stimulation, individual consideration and contingent reward, active management with the exception and passive management with the exception of being done very well by the leader and considered effective in its implementation. The findings of the competence variable indicate that employees have very high competence, which means that the intellectual competencies, emotional competencies and social competencies of employees are very high. While employee performance is very high, meaning that employees have performance in quantity, quality and timeliness are very high.

Based on the results of the analysis using path analysis showed there is a direct influence of leadership on employee performance. The better the leadership, the higher the employee's performance. These findings strengthen the research of Syopwani (2017) and Irjanto \& Setiawan (2016), but are different from Sukwadi \& Yonathan (2014); Bass \& Avolio (1994) who find transactional leadership has a negative influence on employee performance. The leadership in this study used indicators of transformational and transactional leadership. The findings showed that better leadership used will improve employee performance, including the transactional leadership indicators. This result can be explained that in MSMEs the level of education of employees is dominated by high school education level $(71.1 \%)$, even elementary education level $(4.8 \%)$ and junior high school $(21.7 \%)$, so even though in some other studies only transformational leadership who are able to improve performance, in MSMEs with relatively low levels of employee education, leaders must motivate employees by clarifying the roles and demands of the task, and must guide employees in achieving their goals. But leaders who have charisma, have a vision that is oriented towards the future, and able to encourage employees are also needed to improve employee performance.

The results of the analysis showed that the better leadership will improve employee competence. The path coefficient value of the influence of leadership on employee competencies is significant at 0.802 greater than the path coefficient value of leadership influence on performance and the influence of competence on performance. and the social competence of employees will increase. The findings also reinforce the findings of Aris et al.(2011) that the role of the leader as a mentor in guiding employees, in general, makes the employee master the soft competence more optimally in accordance with his basic abilities.

The findings of the study on the influence of competence on employee performance showed significant results with a value of 0.497 . This means that the higher the employee's competence, the higher the employee's performance. Employees who have high intellectual, social and emotional competencies will produce high performance. These results support the findings of McBer (1996) which states that employee performance can be improved through soft competencies and hard competencies. In addition, it is in line with the research of Martadiredja (2010) who found results that competence had a significant effect on performance.

The influence of Leadership on employee performance with competence as a mediating variable using the Sobel test found significant results, meaning that the better or effective leadership, will improve employee competence and ultimately improve employee performance. The role of competence in this study is a partial mediation on the influence of leadership on employee performance, which means that leadership can directly improve employee performance, but also through employee competence variables. The role of competence becomes very important because the value of path analysis on the influence of leadership on competence has the highest coefficient value. These results reinforce the findings of McShane \& Von Glinow (2000) which states that leadership and competence become one of the factors that influence employee behaviour and performance. 


\section{Conclusion}

The research findings are summarized as follows: (1) Leadership in MSMEs in the category is very good or effective, employee competence and performance are very high; (2) Leadership has a significant effect on employee performance. The better and effective leadership, the higher the employee's performance; (3) Leadership has a significant effect on employee competence. The better and effective leadership, it can improve employee competence, (4) Competence has a significant influence on employee performance. The higher the employee's competence, the higher the employee's performance. (5) Competence mediates the influence of leadership on employee performance. This shows that the better and effective leadership, it can improve employee competencies and ultimately improve employee performance.

Suggestions for MSME actors that transformational and transactional leadership can be done simultaneously to improve employee competence and performance. Leaders can increase more coaching time for employees, appreciate work processes more than just see the final results of work and leaders care more about everything that employees do, not only when problems occur because based on the results of the analysis of the scale has the lowest value compared to other items. While suggestions for other researchers can expand MSMEs in other fields, such as MSMEs in the service sector, and can add other variables, namely knowledge sharing, and organizational culture considering there are still other variables that affect performance other than leadership and competence. Limitations of this study: (1) only examines employee performance and does not further examine the performance of MSMEs; and (2) is only limited to aspects of human resources and does not discuss non-human resource aspects, because in addition to HR the success of MSMEs is also determined by non-HR factors.

\section{References}

Abdullah, M. (2013). Manajemen Bisnis Syariah. Aswaja Pressindo.

Arie, P. (2012). Pengaruh Kompetensi dan Motivasi terhadap Kinerja Karyawan PT Indo Stationery Ritel Utama Cabang Samarinda. Publikasi Ilmiah Fakultas Ekonomi Universitas Mulawarman, 1(1).

Aris, W., Hubeis, M., Affandi, J., \& Hermawan, A. (2011). Faktor- Faktor yang Mempengaruhi Kompetensi Kerja Karyawan (Determinants for Employee's work Competencies). Manajemen IKM, 6(2 ISSN 2085-8418).

Bass, B. M., \& Avolio, B. . (1994). Improving Organizational Effectiveness Through Transformational Leadership. Sage Publications Inc.

Cooper, D. R., \& Schindler, P. S. (2014). Business Research Method, 12th edition. McGraw Hill.

Depkop. (2018). Perkembangan Data Usaha Mikro, Kecil , Menengah Dan Usaha Besar. In www.depkop.go.id (Vol. 2000, Issue 1).

Ghozali, I., \& Latan, H. (2015). Partial Least Square: Konsep, Teknik, dan Aplikasi menggunakan Program SmartPLS 3.0. Badan Penerbit Undip.

Hair, J., W.C., B., BJ., B., \& Anderson. (2015). Multivariate Data Analysis 7th ed. Pearson Prentice Hall

Hasibuan S.P. Malayu. (2006). Manajemen Sumber Daya Manusia. Bumi Aksara.

Irjanto, B., \& Setiawan, H. (2016). Pengaruh Gaya Kepemimpinan dan Motivasi terhadap Kinerja Karyawan pada Industri UMKM di Wilayah D.I. Yogyakarta. Jurnal Maksipreneur, V(2), 15-26.

Martadiredja, T. S. (2010). Pengaruh Budaya Organisasi, Kompetensi, dan Motivasi kerja terhadap Kinerja Dosen. Universitas Pajajaran Bandung.

McBer, H. (1996). People and Competencies, The Route to Competitive Advantage. Kogan Page Limited.

McShane, S. ., \& Von Glinow, M. . (2000). Organizational Behavior: Emerging realities for the Workspace Revolution. McGraw-Hill.

Northouse, P. G. (2003). Leadership: Theory and Practice (Third). Response Books.

Prawirosentono, S. (1999). Manajemen Sumber Daya Manusia: Kebijakan Kinerja Karyawan (Pertama). BPFE.

Promis, P. (2008). Are Employer Asking for Right Competencies. Library Administration and Management, 22(1).

Rivai, V., \& Mulyadi, D. (2009). Kepemimpinan dan Perilaku Organisasi edisi ketiga. Rajagrafindo Persada.

Robbins, S. P., \& Timothy A. Judge. (2008). Organizational Behavior, 12th ed. Diana Angelica (penerjemah). Perilaku Organisasi. Salemba Empat.

Spencer, M. L., \& Spencer. (1993). Competence at Work Models for Superior Performance. John Wiley \& Sons, Inc.

Sukwadi, R., \& Yonathan. (2014). Analisis Pengaruh Gaya Kepemimpinan dan Komunikasi Interpersonal terhadap Kinerja UKM. Jurnal Teknik Dan IImu Komputer Program Studi Teknik Industri Universitas Katolik Indonesia Atma Jaya. 
Syopwani. (2017). Pengaruh Kepemimpinan dan Kompetensi terhadap Kinerja Pegawai kantor Kecamatan Pancoran Kota Administrasi Jakarta Selatan. Jurnal Renaissance, 2(1).

Yukl, G. (2010). Leadership on Organization. Pearson Prentice Hall. 